\title{
EFFECT OF PROBIOTIC COMPOSITION ON OXIDATIVE/ANTIOXIDANT BALANCE IN BLOOD OF RATS UNDER EXPERIMENTAL OSTEOARTHRITIS
}

\author{
O. KOROTKYI, K. DVORSHCHENKO, A. VOVK, A. DRANITSINA, \\ M. TYMOSHENKO, L. KOT, L. OSTAPCHENKO \\ ESC "Institute of Biology and Medicine", \\ Taras Shevchenko National University of Kyiv, Ukraine; \\ e-mail: korotky@ukr.net
}

Received: 20 June 2019; Accepted: 18 October 2019

Osteoarthritis (OA) is a widespread pathology of the musculoskeletal system. OA may associate with a wide range of disorders, that lead to the development of various strategies on how to prevent and treat the disease. Recent studies discussed interactions between the microbiome and a wide range of pathologies, including $O A$. In this study, we investigated the effect of probiotic cultures on oxidative/antioxidant balance in blood of rats during $O A$. Experimental $O A$ was induced by a single injection of sodium monoiodoacetate into the knee joint. A probiotic composition (Multiprobiotic Simbiter $\left.{ }^{\circledR}\right)$ was administered by peroral catheter once per day for 14 days. We investigated the next parameters: expression of Nos 2 gene in the blood, superoxide dismutase activity, catalase activity, glutathione peroxidase activity, glutathione transferase activity, glutathione reductase activity, contents of superoxide, hydrogen peroxide, TBA-reactive compounds, oxidized and reduced glutathione in the serum of the blood. Monoiodoacetate-induced OA caused significant changes on oxidativelantioxidant balance in the blood of rats: increasing of the contents of superoxide anion radical, hydrogen peroxide, thiobarbituric acid-reactive compounds, oxidized glutathione, upregulating of Nos 2 expression, increasing of catalase activity; conversely, superoxide dismutase activity, glutathione peroxidize activity, glutathione transferase activity, glutathione reductase activity, the content of reduced glutathione were significantly decreased, compared to control group. Administration of probiotics to animals with OA led to positive changes in the studied parameters approaching the values of control group (some of them were statistically significant).

Keywords: experimental osteoarthritis, microbiome, free radical processes, glutathione.

$\mathrm{O}$ steoarthritis (OA, also known as degenerative disorders of joints) is the most widespread form of arthritis [1]. The prevalence of OA varies among the population; however, it has a strong correlation with age. OA is a frequent cause of long-term incapacity for mid-age workers: OA of the knee joint is detected in $20 \%$ of people over 65 , OA of the brush joints is observed in $22 \%$ of men and $33 \%$ of women over 70 years [2]. Metabolic, collagen or endocrine disorders, mechanical injuries, infectious diseases, increase the risk of OA development. OA can be considered as a group of separate diseases that may have different etiologies, but it overlaps with similar biological, morphological and clinical changes of the body [3]. Development of any state of the organism that the immune system recognizes as unusual causes the development of oxidative stress [4]. It involves a disturbance in the oxidative/antioxidant status, leading to a disruption of redox signaling and molecular damage [5]. Studies of the last decades have shown a variety of oxidative stress signaling during OA. These mechanisms cause synovial inflammation, subchondral bone and mitochondrial dysfunction, chondrocytes senescence, apoptosis and cartilage degradation [6]. The relevance of oxidative stress was widely discussed during a progression of

(C) 2019 Korotkyi O. et al. This is an open-access article distributed under the terms of the Creative Commons Attribution License, which permits unrestricted use, distribution, and reproduction in any medium, provided the original author and source are credited. 
OA [7], and also some related disorders like rheumatoid arthritis [8]. The continuous disturbance of oxidative/antioxidant status changes the interaction between intestinal mucosa, symbiotic bacteria and dietary factors [9], that causes significant changes in varieties of the microbiome [10] it leads to the development of digestive, immune, urinary-sexual and other disorders [11]. The gut microbiota and its metabolic derivatives have closely related to different physiological aspects of the host's organism, such as metabolism, immunity, development, life expectancy, etc [10]. That is why development of strategies to support microbiome is important.

The recent studies have investigated effects of composition that beneficially affect the gut microbiota like probiotics (PB) and prebiotics [12]. Administration of PB has been the subject of research in the past few decades to keep normal microbiota of the intestinal gut. It is mono- or polycomplex of some bacteria strains (mostly Lactobacillus and Bifidobacterium genus). PBs have a wide range of describing effects, such as gut health improvement, antiallergy effect, anticancer activity, relieving lactose intolerance, anti-inflammatory and immunomodulatory effect $[13,14]$. PB supplements decrease oxidative stress during many pathologies like obesity [15], type 2 diabetes [16], pregnancy [17], musculoskeletal disorders [18], etc. PB has a potential role in curing immune disorders, including rheumatic diseases [19, 20]. It opens a wide possibility to describe complex interactions between microbiota and host body. However, administration of PB has a risk turn into opportunistic pathogens, plasmid-mediated antibiotic resistance transfer [21]. Thus, preclinical studies of PB compositions for different uses are highly necessary.

There are a few strategies of preclinical investigations of medication and nutritional supplements. Animal models of OA allow to show complex structural changes in tissues over time and to determine how constitutive, environmental of biomechanical risk factors may initiate, promote and regulate changes of the body [22]. Induction of monoiodoacetate (MIA) into the patellofemoral joint of an experimental rat model induces histopathological changes in the knee joint that similar to those during tibiofemoral OA [23]. MIA-induced model of OA (MIA$\mathrm{OA})$ in rats is widely used to describe morphology, loss of mobility and biochemistry of the disease $[24,25]$, significant changes of cytokine profile [26].
In the present study, we investigated the effect of the PB composition on the oxidative/antioxidant balance in blood of rats under MIA-OA.

\section{Materials and Methods}

Animals. This study followed the ethical principles of European Convention for the protection of vertebrate animals used for experimental and other scientific purposes (Strasbourg, 1986) and the First National Congress of Ukraine on Bioethics (September 2001). The experiments were conducted on white male non-linear rats (8 weeks old, weighing 180-240 g). The animals were bred and hold in the vivarium of the Taras Shevchenko National University of Kyiv, at $12 \mathrm{~h}$ light $/ 12 \mathrm{~h}$ dark cycle, $18-23^{\circ} \mathrm{C}$ and $40-60 \%$ humidity. The randomized rats were divided into four experimental groups, each animal was weighed once a week to correct therapeutic doses. The total number of animals involved in experimental studies was 20 individuals.

Induction of MIA-OA. The model induced by injection of $0.05 \mathrm{ml}$ of saline containing $1 \mathrm{mg}$ sodium monoiodacetate (MIA; Sigma, USA) in the patellar ligament of left hind knee (or saline only as a control for MIA). According to the model description, the gross lesions were first visible at 28 days and consisted of a well-demarcated area of cartilage erosion [27].

Probiotic composition. Probiotic composition Multiprobiotic Simbiter ${ }^{\circledR}$ provided by O.D. Prolisok (Ukraine). This complex included live symbiotic biomass that contains 14 strains of microorganisms belonging to 10 species: Bifidobacterium bifidum, B. longum, Lactobacillus acidophilus, L. delbrueckii, L. helveticus, Propionibacterium freudenreichii, P. acidipropionici, Lactococcus lactis, Acetobacter aceti, Streptococcus salivarius. Manufacturer recommendation of the $\mathrm{PB}$ composition suggested 1 per day administration during at least 10 days course (14 days in this study) [28]. The animals got probiotic composition by peroral catheter at a dose of $140 \mathrm{mg} / \mathrm{kg}$ diluted in fresh water (or fresh water only as a control for probiotic composition).

Study design. The first group - control: the animals got injection of saline on the first day and oral administration of water daily for 14 days from the $8^{\text {th }}$ to the $21^{\text {st }}$. The second group - PB: the animals got injection of saline on the first day and oral administration of the PB composition daily for 14 days from the $8^{\text {th }}$ to the $21^{\text {st }}$ day. The third group - MIA-OA: 
the animals got injection of MIA on the first day and oral administration of water daily for 14 days from the $8^{\text {th }}$ to the $21^{\text {st }}$. The fourth group - MIA-OA+PB: the animals got injection of MIA on the first day and oral administration of the PB composition daily for 14 days from the $8^{\text {th }}$ to the $21^{\text {st }}$ day.

Sample preparation. The blood sampling was conducted on the $30^{\text {th }}$ day of the experiment. All animals got food deprivation with free access to water for $24 \mathrm{~h}$ before. All animals were sacrificed, according to the protocol of the ethics committee. $1 \mathrm{ml}$ of each sample were mixed well with $6 \%$ ethylendiaminetetraacetic acid, 1:20 and stored at $-20^{\circ} \mathrm{C}$ in plastic tubes for no more than 1 month for further real-time PCR test (in this study, Nos2 gene expression only) [29]. Rest of the blood was collected to glass tubes, incubated in a thermostat at $37^{\circ} \mathrm{C}$ for $30 \mathrm{~min}$, then centrifugated at $1000 \mathrm{rpm} / \mathrm{min}$ for $15 \mathrm{~min}$. Serum supernatant aliquoted to plastic tubes and stored at $-80^{\circ} \mathrm{C}$ for no more than 3 months for further biochemical tests (all, except Nos2 gene expression).

Reactive oxygen species and thiobarbituric acidreactive compounds. The superoxide anion radical was tested by the formation of HTT-formazan [30]. Hydrogen peroxide was measured in sorbitol-xylenol orange [31, 32]. Thiobarbituric acid (TBA)-reactive compounds was determined by reaction with TBA [33].

Nos2 gene expression. RNA was obtained by the Chomczynski method [34]. A quantitative polymerase chain reaction was performed in real-time (RT-qPCR) using the commercial kit Thermo Scientific Verso SYBR Green 1-Step qRT-PCR ROX Mix (Thermo Scientific, Lithuania). The following primer sequences were used in the reactions (selected using Primer-BLAST): for Nos2 - forward GTGTTCCACCAGGAGATGTTG and reverse TGTCAGAAACTCAGGCGTAGT; for Actb - forward - TGGGACGATATGGAGAAGAT and reverse - ATTGCCGATAGTGATGACCT.

Antioxidant activity. Superoxide dismutase activity was tested by the ability of the enzyme to compete with nitrosin tetrazolium for superoxide anion radicals [35]. The catalase activity was measured by the amount of undiluted hydrogen peroxide in the sample [36].

Glutathione-dependent antioxidant system. Glutathione peroxidase (GP) activity was evaluated by decreasing reduced glutathione (GSH) content in reaction with the Elman reagent [37]. Glutathione transferase (GT) activity was determined by the rate of formation of the GSH conjugate with 1-chloro-2,4-dinitrobenzene [37]. Glutathione reductase (GR) activity was measured by decreasing the optical density of the samples during the oxidation of NADPH [37].

GSH and oxidized glutathione. The contents of GSH and oxidized glutathione (GSSG) were determined by the spectrofluorimetric method using $O$-phthaldehyde at different $\mathrm{pH}$ values $[38,39]$.

Statistical analysis. The results were presented as average arithmetic \pm standard deviation (dispersion) - SD. Normal distribution was checked via the Shapiro-Wilk test for normality and conducted to one-way ANOVA with Tukey's post hoc test for multiple comparisons. Two-sided $P \leq 0.05$ was considered statistically significant. The results were analyzed using GraphPad Prism 5.04 (GraphPad Software Inc., USA).

\section{Results and Discussion}

Inflammatory and destructive processes of the joints play a key role in the development of OA. Many studies documented the relationship between inflammation and oxidative stress in various pathological conditions [40-42]. The oxidative stress stimulated development and progression of inflammation in joints. Activated phagocytes and hypoxic processes cause the permanent generation of free radicals. This leads to death of synovial cells, destruction of cartilage tissue, erosion of bones and articular surfaces. Moreover, the pool of antioxidative components could be depleted and caused downregulation of antioxidative defence. It contributes to the pathology of joints [43].

In this study, MIA-OA caused increasing of the content of superoxide anion radical in 2.3 times, hydrogen peroxide - in 2.4 times and TBA-reactive compounds - in 2.1 times, respectively, according to Control group (Table 1).

Also, we measured the expression of the Nos2 gene that encoding the inducible NO-synthase. MIA-OA up-regulated the expression of Nos2 gene in 3.1 times compared to control group in blood of the animals (Fig).

MIA-OA activated free radical processes that caused the accumulation of superoxide anion radicals, hydrogen peroxide and nitric oxide (increased expression of the Nos2 gene) and TBA-reactive compounds - intermediate products of lipid peroxidation. In this state, the balance between intensity of the formation of free radicals and their neutralization by 
Ta b le 1. The content of reactive oxygen species and TBA-reactive compounds in blood serum of rats under monoiodoacetate-induced osteoarthritis (MIA-OA) and administration of probiotic (PB) composition ( $\pm \pm m$, $n=5)$

\begin{tabular}{|c|c|c|c|c|}
\hline \multirow{2}{*}{ Parameter } & \multicolumn{4}{|c|}{ Group } \\
\hline & Control & PB & MIA-OA & $\mathrm{MIA}-\mathrm{OA}+\mathrm{PB}$ \\
\hline $\begin{array}{l}\text { Superoxide anion radical, } \mu \text { mol } \\
\text { XTT formazan } \times \text { mg protein }^{-1}\end{array}$ & $4.83 \pm 0.45$ & $4.61 \pm 0.42$ & $10.93 \pm 0.98^{*}$ & $6.29 \pm 0.54^{* / \hbar}$ \\
\hline Hydrogen peroxide, $\mu$ mol $\times$ mg protein ${ }^{-1}$ & $0.35 \pm 0.03$ & $0.32 \pm 0.03$ & $0.84 \pm 0.08^{*}$ & $0.48 \pm 0.04^{* / / 7}$ \\
\hline $\begin{array}{l}\text { TBA-reactive compounds, } \\
\text { nmol } \times \text { mg protein }^{-1}\end{array}$ & $7.05 \pm 0.68$ & $6.59 \pm 0.64$ & $14.63 \pm 1.32 *$ & $9.58 \pm 0.93^{* / \#}$ \\
\hline
\end{tabular}

$* P<0.05$ compared with control group; ${ }^{\#} P<0.05$ compared with MIA-OA group.

the antioxidant defence system is disturbed. Administration of PB caused reduction of the content of superoxide anion radical in 1.7 times, hydrogen peroxide - 1.8 times, TBA-reactive compounds - 1.5 times (Table 1) and the expression of the Nos2 gene - 2.2 times, respectively, compared with MIA-OA group (Fig.) and these parameters approached to levels of control group.

Superoxide dismutase and catalase regulate the level of reactive metabolites of oxygen. Superoxide dismutase catalyzes the transmutation of the superoxide radical into hydrogen peroxide. Catalase is an enzyme that activated the process of splitting hydrogen peroxide into water. Their cooperated work is an important factor that influences the concentration of free radicals in the body.

The study showed reducing activity of superoxide dismutase in the condition of MIA-OA in 1.6 times, while catalase activity had few tendencies

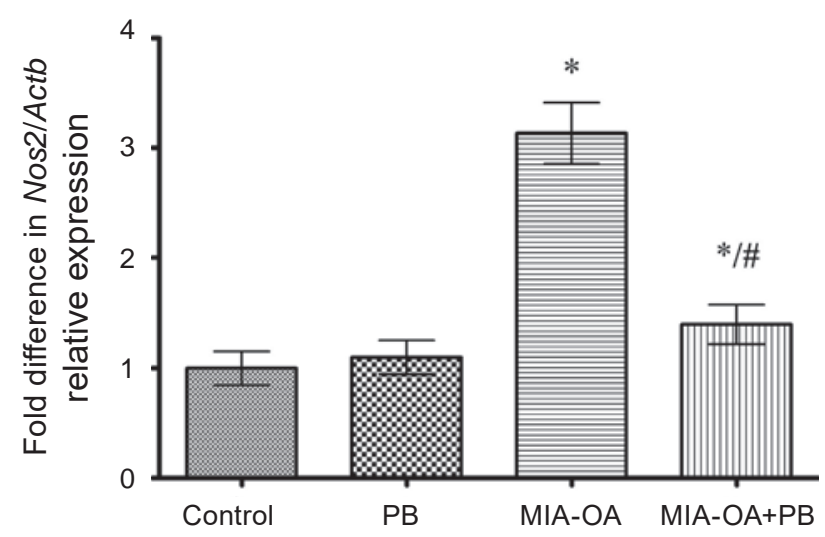

Expression of Nos2 gene in blood of rats under monoiodoacetate-induced osteoarthritis (MIA-OA) and administration of probiotic (PB) composition ( $M \pm m, n=5) . * P<0.05$ compared with control group; ${ }^{\sharp} P<0.05$ compared with MIA-OA group to increase with insignificant changes statistically, compared to control group (Table 2).

Low activity of superoxide dismutase in blood serum of rats with MIA-OA may be a result of increased content of free radicals that can cause oxidation of amino acids in the active center of the enzyme. It leads to conformational changes and loss of functional activity. Hydrogen peroxide can inactivate superoxide dismutase activity due to the oxidation of several histidine residues of apoprotein and the reduction of $\mathrm{Cu}^{2+}$ to $\mathrm{Cu}^{+}$[44-46]. Administration of PB to animals with MIA-OA partly restored the enzyme activity of antioxidant system: superoxide dismutase activity increased by 1.3 times, and catalase activity showed close values, compared with control group (Table 2).

Glutathione-dependent antioxidant system (GDAS) plays an important role in the detoxification, degradation and excrection of foreign substances from the body. Except for glutathione, GDAS includes enzymes such as GP, GR, GT etc. [47, 48]. In this study, GP activity decreased in MIA-OA group in 1.5 times, compared to control group (Table 3). Administration of probiotic composition to animals with OA (MIA-OA+PB group) increased GP activity in 1.4 times compared with MIA-OA group (Table 3) and reached the level of control group.

GT activity decreased in 1.6 times in blood serum of rats with MIA-OA, compared to control group (Table 3). Decreasing of GT activity may be a response to an excess of toxic oxygen metabolites, due to the development of the inflammatory process $[26,49]$. GT is highly specific to reduced glutathione, and a decrease in GSH pool can cause a decrease in enzyme activity [50].

Administration of the PB composition to animals with MIA-OA increased values of GT activity in 1.3 times compared to MIA-OA rats and ap- 
Ta b le 2. Antioxidant enzymes activity in blood serum of rats under monoiodoacetate-induced osteoarthritis (MIA-OA) and administration of probiotic (PB) composition $(M \pm m, n=5)$

\begin{tabular}{l|c|c|c|c}
\hline \multirow{2}{*}{ Parameter } & \multicolumn{4}{c}{ Group } \\
\cline { 2 - 5 } & Control & PB & MIA-OA & MIA-OA+PB \\
\hline Superoxidedismutase activity, & $0.21 \pm 0.02$ & $0.19 \pm 0.02$ & $0.13 \pm 0.01^{*}$ & $0.17 \pm 0.01^{* / \#}$ \\
unit $\times \mathrm{min}^{-1} \times \mathrm{mg} \mathrm{protein}^{-1}$ & $0.71 \pm 0.06$ & $0.74 \pm 0.07$ & $0.86 \pm 0.09$ & $0.65 \pm 0.06^{\#}$ \\
Catalase activity, nmol $\times \mathrm{min}^{-1} \times \mathrm{mg} \mathrm{protein}^{-1}$ &
\end{tabular}

$* P<0.05$ compared with control group; ${ }^{\#} P<0.05$ compared with MIA-OA group.

proached the values to control group. Enhance GT activity may indicate neutralization of lipid peroxidation products, and other xenobiotics as a result of nucleophilic substitution and accession [51, 52]. GT does not affect hydrogen peroxide, but it shows GPliked activity to an endogenous substrate such hydroperoxides of polyunsaturated fatty acids. Thus, enhance the activity of GT may be concerned as a compensatory reaction during inhibition of GP activity [53], and it leads to normalization of GT activity in groups with PB administration.

MIA-OA depressed GR activity in 1.3 times compared to control group (Tab. 3). Decreasing of GR activity causes a decline of blood ability to maintain the physiological content of GSH in the reaction of reduction GSSG to GSH [54]. Administration of $\mathrm{PB}$ to MIA-OA animals associated with enhancing of GR activity in 1.4 times compared to MIA-OA animals without PB (Table 3). An increase of GR activity in blood serum of $\mathrm{PB}$ groups may indicate an increased ability of blood to reduct GSSG. Thus, probiotic bacteria include in the composition can increase the content of GSH indirectly [55].

MIA-OA decreased the content of GSH in blood serum in 1.5 times compared to control group (Table 4). The fall of GSH in blood serum can be the compensatory reaction of the body to oxida- tive stress and inflammation. Enhance processes of glutathione-dependent recovery of SH-groups play defence role during oxidative stress, providing intensive S-glutathionation of proteins and preservation of proteins. The decrease GSH indicates oxidation of $\mathrm{SH}$ group in cysteine residues, the progression of lipid peroxidation and the appearance of its secondary metabolites as a result of oxidative stress [54, 55].

Administration of PB to animals with MIA-OA increased the content of GSH in 1.3 times compared to pathology group (Table 4). We think probiotic bacteria of PB composition can induce synthesis of GSH indirectly, as it was shown in the intestinal mucosa of rats with acute pancreatitis [53]. Increasing of GSH is also associated with with a partial restoration of the redox blood status of rats during experimental of OA.

MIA-OA increased the content of GSSG in 1.4 times in blood serum of rats, compared to the control group (Table 4). Administration of PB composition to animals with MIA-OA decreased the content of GSSG in 1.3 times, compared to animals with OA, but it was higher than the values of control group. The experimental model of OA disturbs ratio between GSH and GSSG in blood serum of rats. PB supports the restoration of the balance between oxidized and reduced forms of glutathione. The administration of PB composition to animals

Ta b le 3. Enzymes activity of glutathione dependent antioxidant system in blood serum of rats under monoiodoacetate-induced osteoarthritis (MIA-OA) and administration of probiotic (PB) composition $(M \pm m, n=5)$

\begin{tabular}{|c|c|c|c|c|}
\hline \multirow{2}{*}{ Parameter } & \multicolumn{4}{|c|}{ Group } \\
\hline & Control & $\mathrm{PB}$ & MIA-OA & $\mathrm{MIA}-\mathrm{OA}+\mathrm{PB}$ \\
\hline $\begin{array}{l}\text { Glutathione peroxidase activity, } \\
\text { nmol GSH } \times \min ^{-1} \times \text { mg protein }\end{array}$ & $30.95 \pm 2.73$ & $35.29 \pm 3.14$ & $20.36 \pm 1.89 *$ & $27.85 \pm 2.51^{\#}$ \\
\hline $\begin{array}{l}\text { Glutathione transferase activity, } \\
\text { nmol } \times \min ^{-1} \times \mathrm{mg} \text { protein } \\
-1\end{array}$ & $7.08 \pm 0.64$ & $7.79 \pm 0.71$ & $4.49 \pm 0.42^{*}$ & $5.65 \pm 0.51^{\# / *}$ \\
\hline $\begin{array}{l}\text { Glutathione reductase activity, } \\
\text { nmol NADPH } \times \min ^{-1} \times \text { mg protein }\end{array}$ & $0.36 \pm 0.03$ & $0.39 \pm 0.03$ & $0.29 \pm 0.02 *$ & $0.41 \pm 0.04^{\#}$ \\
\hline
\end{tabular}

${ }^{*} P<0.05$ compared with control group; ${ }^{\#} P<0.05$ compared with MIA-OA group. 
Table 4. The content of reduced (GSH) and oxidized (GSSG) glutathione in blood serum of rats under monoiodoacetate-induced osteoarthritis (MIA-OA) and administration of probiotic (PB) composition ( $M \pm m$, $n=5)$

\begin{tabular}{|c|c|c|c|c|}
\hline \multirow{2}{*}{ Parameter } & \multicolumn{4}{|c|}{ Group } \\
\hline & Control & PB & MIA-OA & $\mathrm{MIA}-\mathrm{OA}+\mathrm{PB}$ \\
\hline $\mathrm{GSH}, \mathrm{nmol} \times \mathrm{mg}$ protein $^{-1}$ & $19.17 \pm 1.56$ & $24.78 \pm 2.15^{*}$ & $12.95 \pm 1.08 *$ & $16.19 \pm 1.28^{\# / *}$ \\
\hline GSSG, nmol $\times$ mg protein ${ }^{-1}$ & $5.98 \pm 0.55$ & $5.71 \pm 0.54$ & $8.49 \pm 0.76^{*}$ & $6.59 \pm 0.57^{\# / *}$ \\
\hline
\end{tabular}

$* P<0.05$ compared with control group; ${ }^{\#} P<0.05$ compared with MIA-OA group.

without MIA injection (PB group) made no significant changes in studied parameters of blood serum, compared to the values of control group (except GSH that described above).

Summarising the data, we suggest that MIAOA has some significant effects on oxidative/antioxidant status in blood of rats. These experimental conditions lead to enhance the synthesis of reactive oxygen and nitrogen species, and TBA-reactive compounds that formed as products of lipids peroxidation. It associated with changes in superoxide dismutase activity during experimental OA. Also, there was a violation of GDAS: GP, GT, GR activities and the content of GSH decreased significantly, while the content of GSSG was extremely high.

Thus, an increase circulating of free radicals in the blood contributes to the development of oxidative stress in the body, and it is tightly linked with decreasing of antioxidant capacity. This is one of the important non-specific pathogenetic mechanisms of general inflammation [7]. The relationship between oxidative stress and the etiology of OA can provide a new approach to understand and, accordingly, to control the progression of the disease. Our previous studies showed disbalance of cytokine status in blood with the prevalence of pro-inflammation cytokines and significant up-regulation of Ptgs2 expression in knee cartilage during OA [56, 57].

This study shows restoration of oxidative-antioxidant balance in blood of rats at the long-term introduction of the PB composition. The mechanism of the antioxidant effect of PB under these experimental conditions is unknown and should be inves- tigated. The effectiveness of PB may be associated with a wide range of its biological activity. The possible mechanism of PB effectiveness activity may be based on its ability to eliminate microecological disorders and reduce inflammatory processes at the local and systemic levels of the body. Moreover, the bacterial strains are active producers of physiologically active metabolites: vitamins, short-chain fatty acids, antioxidants and immunomodulators, which extends the spectrum of biological effects of $\mathrm{PB}$ compositions [58-60].

The experimental MIA-OA caused oxidative stress in blood of rats (enlarge the content of reactive oxygen species, TBA-reactive compounds, expression of Nos2, decrease superoxide dismutase activity, GP, GR, GT activity and GSH:GSSG ratio). Administration of the PB composition to animals with OA contributed to the restoration of oxidativeantioxidant balance.

Acknowledgments. The study was supported by the budget topic of Ministry of Education of Ukraine 18БП036-02 "Development of methodical recommendations for administration of chondroprotectors and multiprobiotics for correction of joint pathology. Applied scientific research" (2018-2020 academic years).

Conflict of interest. Authors have completed the Unified Conflicts of Interest form at http://ukrbiochemjournal.org/wp-content/uploads/2018/12/ coi_disclosure.pdf and declare no conflict of interest. 
ВПЛИВ ПРОБІОТИЧНОЇ КОМПОЗИЦЇ̈ НА ОКСИДАНТНО/ АНТИОКСИДАНТНИЙ БАЛАНС У КРОВІ ЩУРІВ ЗА ЕКСПЕРИМЕНТАЛЬНОГО ОСТЕОАРТРИТУ

\author{
О. Г. Короткий, К. О. Дворщенко, \\ А. А. Вовк, А. А. Драницина, \\ М. О. Тимошенко, Л. I. Кот, \\ Л. I. Остапченко
}

\author{
ННЦ «Інститут біології та медицини», \\ Київський національний університет \\ імені Тараса Шевченка, Україна; \\ e-mail: korotky@ukr.net
}

Остеоартрит (OA) є широко розповсюдженою паталогією опорно-рухової системи. Розвиток ОА пов'язаний із широким діапазоном причин, що впливають на створення різноманітних стратегій профілактики та лікування цього захворювання. На сьогодні активно обговорюється вплив мікробіому на широкий перелік паталогій, в тому числі опорно-рухової системи. У роботі досліджено вплив живих пробіотичних культур на оксидантно/антиоксидантний стан у крові щурів за ОА. Експериментальний ОА в щурів моделювали одноразовим введенням розчину монойодацетату натрію в колінну зв'язку. Пробіотична композиція (мультипробіотик Симбітер ${ }^{\circledR)}$ вводилася перорально зондом 1 раз на добу протягом 14 днів. Визначено: експресію гена Nos2 в крові, значення супероксиддисмутазної, каталазної, глутатіонпероксидазної, глутатіонтрансферазної, глутатіонредуктазної активності, вміст супероксиданіону, пероксиду водню, ТБК-активних продуктів, окисленого та відновленого глутатіону в сироватці крові. Встановлено, що монойодацетатіндукований OA спричинював значні зміни оксидантно/антиоксидантного стану в крові щурів. Показано підвищення рівнів супероксиданіонного радикалу, пероксиду водню, ТБК-активних продуктів, окисленого глутатіону, посилення експресії Nos2 та підвищення каталазної активності в той час як супероксиддисмутазна, глутатіонпероксидазна та глутатіонтрансферазна активність, глутатіонредуктазна активність і рівень відновленого глутатіону були значно знижені порівняно $з$ контрольною групою. Введення пробіотиків тваринам із ОА наближало досліджувані пара- метри до значень контрольної групи (деякі з них були статистично значимими).

К л ю чов в с с о в а: експериментальний остеоартрит, мікробіом, вільнорадикальні процеси, глутатіон.

\section{References}

1. Man GS, Mologhianu G. Osteoarthritis pathogenesis - a complex process that involves the entire joint. J Med Life. 2014; 7(1): 37-41.

2. O'Neill TW, McCabe PS, McBeth J. Update on the epidemiology, risk factors and disease outcomes of osteoarthritis. Best Pract Res Clin Rheumatol. 2018; 32(2): 312-326.

3. Hunter DJ, Bierma-Zeinstra S. Osteoarthritis. Lancet. 2019; 393(10182): 1745-1759.

4. Sies H. Oxidative stress: a concept in redox biology and medicine. Redox Biol. 2015; 4: 180183.

5. Lushchak VI. Free radicals, reactive oxygen species, oxidative stress and its classification. Chem Biol Interact. 2014; 224: 164-175.

6. Lepetsos P, Papavassiliou AG. ROS/oxidative stress signaling in osteoarthritis. Biochim Biophys Acta. 2016; 1862(4): 576-591.

7. Ziskoven C, Jäger M, Zilkens C, Bloch W, Brixius $K$, Krauspe R. Oxidative stress in secondary osteoarthritis: from cartilage destruction to clinical presentation? Orthop Rev (Pavia). 2010; 2(2): e23.

8. Quiñonez-Flores CM, González-Chávez SA, Del Río Nájera D, Pacheco-Tena C. Oxidative Stress Relevance in the Pathogenesis of the Rheumatoid Arthritis: A Systematic Review. Biomed Res Int. 2016; 2016: 6097417.

9. Gyuraszova M, Kovalcikova A, Gardlik R. Association between oxidative status and the composition of intestinal microbiota along the gastrointestinal tract. Med Hypotheses. 2017; 103: 81-85.

10. Szychlinska MA, Di Rosa M, Castorina A, Mobasheri A, Musumeci G. A correlation between intestinal microbiota dysbiosis and osteoarthritis. Heliyon. 2019; 5(1): e01134.

11. Bravo-Blas A, Wessel H, Milling S. Microbiota and arthritis: correlations or cause? Curr Opin Rheumatol. 2016; 28(2): 161-167.

12. Vitetta L, Coulson S, Linnane AW, Butt H. The gastrointestinal microbiome and musculoskeletal diseases: a beneficial role for probiotics and prebiotics. Pathogens. 2013; 2(4): 606-626. 
13. Pandey KR, Naik SR, Vakil BV. Probiotics, prebiotics and synbiotics - a review. J Food Sci Technol. 2015; 52(12): 7577-7587.

14. Savcheniuk O, Kobyliak N, Kondro M, Virchenko O, Falalyeyeva T, Beregova T. Shortterm periodic consumption of multiprobiotic from childhood improves insulin sensitivity, prevents development of non-alcoholic fatty liver disease and adiposity in adult rats with glutamate-induced obesity. BMC Complement Altern Med. 2014; 14: 247.

15. Savini I, Catani MV, Evangelista D, Gasperi V, Avigliano L. Obesity-associated oxidative stress: strategies finalized to improve redox state. Int $J$ Mol Sci. 2013; 14(5): 10497-10538.

16. Kobyliak N, Falalyeyeva T, Mykhalchyshyn G, Kyriienko D, Komissarenko I. Effect of alive probiotic on insulin resistance in type 2 diabetes patients: Randomized clinical trial. Diabetes Metab Syndr. 2018; 12(5): 617-624.

17. Asemi Z, Zare Z, Shakeri H, Sabihi SS, Esmaillzadeh A. Effect of multispecies probiotic supplements on metabolic profiles, hs-CRP, and oxidative stress in patients with type 2 diabetes. Ann Nutr Metab. 2013; 63(1-2): 1-9.

18. Henrotin Y, Lambert C, Couchourel D, Ripoll C, Chiotelli E. Nutraceuticals: do they represent a new era in the management of osteoarthritis? - a narrative review from the lessons taken with five products. Osteoarthritis Cartilage. 2011; 19(1): $1-21$.

19. Abdollahi-Roodsaz S, Abramson SB, Scher JU. The metabolic role of the gut microbiota in health and rheumatic disease: mechanisms and interventions. Nat Rev Rheumatol. 2016; 12(8): 446-455.

20. Yousefi B, Eslami M, Ghasemian A, Kokhaei P, Sadeghnejhad A. Probiotics can really cure an autoimmune disease? Gene Rep. 2019; 15: 100364.

21. Kothari D, Patel S, Kim SK. Probiotic supplements might not be universally-effective and safe: A review. Biomed Pharmacother. 2019; 111: 537-547.

22. Kuyinu EL, Narayanan G, Nair LS, Laurencin CT. Animal models of osteoarthritis: classification, update, and measurement of outcomes. J Orthop Surg Res. 2016; 11(1): 19.

23. Takahashi I, Matsuzaki T, Kuroki H, Hoso M. Induction of osteoarthritis by injecting monosodium iodoacetate into the patellofemoral joint of an experimental rat model. PLoS One. 2018; 13(4): e0196625.

24. Portal-Núñez S, Esbrit P, Alcaraz MJ, Largo R. Oxidative stress, autophagy, epigenetic changes and regulation by miRNAs as potential therapeutic targets in osteoarthritis. Biochem Pharmacol. 2016; 108: 1-10.

25. Korotkyi O, Vovk A, Kuryk O, Dvorshchenko K, FalalyeyevaT,OstapchenkoL.Co-administration of live probiotics with chondroprotector in management of experimental knee osteoarthritis. Georgian Med News. 2018; (279): 191-196.

26. Korotkyi O, Vovk A, Blokhina O, Dvorshchenko K, Falalyeyeva T, Abenavoli L, Ostapchenko L. Effect of Chondroitin Sulfate on Blood Serum Cytokine Profile during Carrageenan-induced Edema and Monoiodoacetate-induced Osteoarthritis in rats. Rev Recent Clin Trials. 2019; 14(1): 50-55.

27. Guzman RE, Evans MG, Bove S, Morenko B, Kilgore K. Mono-iodoacetate-induced histologic changes in subchondral bone and articular cartilage of rat femorotibial joints: an animal model of osteoarthritis. Toxicol Pathol. 2003; 31(6): 619-624.

28. Regime of access : https://symbiter.ua/ uk/multiprobiotics-symbiter-ua/symbiteracidophilic-ua.html

29. Flannery J, Rajko-Nenow P, Hicks H, Hill H, Gubbins S, Batten C. Evaluating the most appropriate pooling ratio for EDTA blood samples to detect Bluetongue virus using realtime RT-PCR. Vet Microbiol. 2018; 217: 58-63.

30. Able AJ, Guest DI, Sutherland MW. Use of a new tetrazolium-based assay to study the production of superoxide radicals by tobacco cell cultures challenged with avirulent zoospores of phytophthora parasitica var nicotianae. Plant Physiol. 1998; 117(2): 491-499.

31. Jiang ZY, Woollard AC, Wolff SP. Hydrogen peroxide production during experimental protein glycation. FEBS Lett. 1990; 268(1): 69-71.

32. Nourooz-Zadeh J, Tajaddini-Sarmadi J, Wolff SP. Measurement of plasma hydroperoxide concentrations by the ferrous oxidationxylenol orange assay in conjunction with triphenylphosphine. Anal Biochem. 1994; 220(2): 403-409.

33. Stalnaia ID, Garishvili TG. A method for determination of malondialdehyde with tiobarbituric acid. Modern methods in 
biochemistry. M.: Meditsina, 1977. P. 66-68 (In Russian).

34. Chomczynski P, Sacchi N. The single-step method of RNA isolation by acid guanidinium thiocyanate-phenol-chloroform extraction: twenty-something years on. Nat Protoc. 2006; 1(2): 581-585.

35. Chevari S, Chaba I, Sekei I. The role of superoxide dismutase in the oxidative processes of the cell and the method for its determination in biological materials. Lab Delo. 1985; (11): 678-681. (In Russian).

36. Koroliuk MA, Ivanova LK, Maiorova IG, Tokarieva VA. A method for determination of catalase. Lab Delo. 1988; (4): 44-47. (In Russian).

37. Vlasova SN, Shabunina EI, Pereslagina IA. The activity of the glutathione-dependent enzymes of erythrocytes in chronic liver diseases in children. Lab Delo. 1990; (8): 19-22. (In Russian).

38. Hissin PJ, Hilf R. A fluorometric method for determination of oxidized and reduced glutathione in tissues. Anal Biochem. 1976; 74(1): 214-226.

39. Mokrasch LC, Teschke EJ. Glutathione content of cultured cells and rodent brain regions: a specific fluorometric assay. Anal Biochem. 1984; 140(2): 506-509.

40. Lugrin J, Rosenblatt-Velin N, Parapanov R, Liaudet $\mathrm{L}$. The role of oxidative stress during inflammatory processes. Biol Chem. 2014; 395(2): 203-230.

41. Pisoschi AM, Pop A. The role of antioxidants in the chemistry of oxidative stress: A review. Eur J Med Chem. 2015; 97: 55-74.

42. Jha JC, Ho F, Dan C, Jandeleit-Dahm K. A causal link between oxidative stress and inflammation in cardiovascular and renal complications of diabetes. Clin Sci (Lond). 2018; 132(16): 18111836.

43. Ziskoven $C$, Jäger $M$, Kircher J, Patzer $T$, Bloch W, Brixius K, Krauspe R. Physiology and pathophysiology of nitrosative and oxidative stress in osteoarthritic joint destruction. Can $J$ Physiol Pharmacol. 2011; 89(7): 455-466.

44. Gottfredsen RH, Larsen UG, Enghild JJ, Petersen SV. Hydrogen peroxide induce modifications of human extracellular superoxide dismutase that results in enzyme inhibition. Redox Biol. 2013; 1(1): 24-31.

45. Jung O, Marklund SL, Xia N, Busse R, Brandes RP. Inactivation of extracellular superoxide dismutase contributes to the development of high-volume hypertension. Arterioscler Thromb Vasc Biol. 2007; 27(3): 470-477.

46. Demicheli V, Moreno DM, Radi R. Human Mn-superoxide dismutase inactivation by peroxynitrite: a paradigm of metal-catalyzed tyrosine nitration in vitro and in vivo. Metallomics. 2018; 10(5): 679-695.

47. Couto N, Wood J, Barber J. The role of glutathione reductase and related enzymes on cellular redox homoeostasis network. Free Radic Biol Med. 2016; 95: 27-42.

48. Dominko K, Đikić D. Glutathionylation: a regulatory role of glutathione in physiological processes. Arh Hig Rada Toksikol. 2018; 69(1): $1-24$.

49. Adly AAM. Oxidative stress and disease: an updated review. Res J Immunol. 2010; 3(2): 129145.

50. Allocati N, Masulli M, Di Ilio C, Federici L. Glutathione transferases: substrates, inihibitors and pro-drugs in cancer and neurodegenerative diseases. Oncogenesis. 2018; 7(1): 8.

51. Singhal SS, Singh SP, Singhal P, Horne D, Singhal J, Awasthi S. Antioxidant role of glutathione S-transferases: 4-Hydroxynonenal, a key molecule in stress-mediated signaling. Toxicol Appl Pharmacol. 2015; 289(3): 361-370.

52. Dong SC, Sha HH, Xu XY, Hu TM, Lou R, Li H, $\mathrm{Wu}$ JZ, Dan C, Feng J. Glutathione S-transferase $\pi$ : a potential role in antitumor therapy. Drug Des Devel Ther. 2018; 12: 3535-3547.

53. Lutgendorff F, Nijmeijer RM, Sandström PA, Trulsson LM, Magnusson KE, Timmerman HM, van Minnen LP, Rijkers GT, Gooszen HG, Akkermans LM, Söderholm JD. Probiotics prevent intestinal barrier dysfunction in acute pancreatitis in rats via induction of ileal mucosal glutathione biosynthesis. PLoS One. 2009; 4(2): e4512.

54. García-Giménez JL, Romá-Mateo C, PérezMachado G, Peiró-Chova L, Pallardó FV. Role of glutathione in the regulation of epigenetic mechanisms in disease. Free Radic Biol Med. 2017; 112: 36-48.

55. Teskey G, Abrahem R, Cao R, Gyurjian K, Islamoglu H, Lucero M, Martinez A, Paredes E, Salaiz O, Robinson B, Venketaraman V. Glutathione as a Marker for Human Disease. Adv Clin Chem. 2018; 87: 141-159. 
56. Korotkyi O, Vovk A, Galenova T, Vovk T, Dvorschenko K, Luzza F, Abenavoli L, Kobyliak N, Falalyeyeva T, Ostapchenko L. Effect of probiotic on serum cytokines and matrix metalloproteinases profiles during monoiodoacetate-induced osteoarthritis in rats. Minerva Biotecnol. 2019; 31(2): 68-73.

57. Dranitsina AS, Dvorshchenko KO, Korotkiy AG, Grebinyk DM, Ostapchenko LI. Expression of Ptgs2 and Tgfb1 genes in rat cartilage cells of the knee under conditions of osteoarthritis. Cyt Gen. 2018; 52(3): 192-197.

58. Plaza-Diaz J, Ruiz-Ojeda FJ, Gil-Campos M, Gil A. Mechanisms of action of probiotics. Adv Nutr. 2019; 10(S1): S49-S66.
59. Vaghef-Mehrabany E, Homayouni-Rad A, Alipour B, Sharif SK, Vaghef-Mehrabany L, Alipour-Ajiry S. Effects of Probiotic Supplementation on Oxidative Stress Indices in Women with Rheumatoid Arthritis: A Randomized Double-Blind Clinical Trial. J Am Coll Nutr. 2016; 35(4): 291-299.

60. Liu X, Zeng B, Zhang J, Li W, Mou F, Wang H, Zou Q, Zhong B, Wu L, Wei H, Fang Y. Role of the gut microbiome in modulating arthritis progression in mice. Sci Rep. 2016; 6: 30594. 